\title{
International Trends in the Field of Forensic Science Standardization, Forensic Science Standardization in Europe, Experience of Bosnia and Herzegovina
}

\section{Ljiljana Trišić}

Independent Expert on Internal Affairs and Security, Bijeljina 76300, Bosnia and Herzegovina

\begin{abstract}
The subject of this work is to present forensic science standardization trends in the world and in Europe with special review of the application of ISO/IEC 17025:2005 standard, which is a condition for forensic laboratory accreditation. Through the analysis of needs and constant efforts to make the forensic area simpler for cooperation and more practical for use, as well as to improve the quality of forensic analysis results and their acceptance beyond the borders of a country, the author will try to point out the significance of implementing this international standard, in terms of economics and cost-effectiveness, as well as overall rationality.

Accepting and exchanging the best professional and scientific experiences, professional help and cooperation in the form of international exchange of forensic data bases, and unreserved acceptance of valid forensic laboratory results ensure the quality the forensic science and profession are striving for, as shown in the EU document titled "Creating a common European space for the forensic sciences 2020". We believe that forensic activity standardization in Bosnia and Herzegovina will help in fighting terrorism and organized crime more effectively. In other words, the process of forensic analysis will be more valid and practical, forensic laboratories more competent, and court proceedings more effective through norming the forensic handling of evidence. Thus an important obligation of Bosnia and Herzegovina on its way to European integration will be fulfilled, because once a forensic laboratory receives an affirmation for its results, it becomes a benchmark for forensic analyses and crime detection.
\end{abstract}

Keywords: forensic science, standardization, ISO 17025, accreditation

For citation: Trišić L. International Trends in the Field of Forensic Science Standardization, Forensic Science Standardization in Europe, Experience of Bosnia and Herzegovina. Theory and Practice of Forensic Science. 2018. Vol. 13. No. 3. P. 116-122. https://doi.org/10.30764/1819-2785-2018-13-3-116-122

\section{Международные тенденции в области стандартизации судебно-экспертной деятельности, стандартизация судебной экспертизы в Европе, опыт Боснии и Герцеговины}

\section{Л. Тришич}

Независимый эксперт по внутренним делам и безопасности, Биелина 76300, Босния и Герцеговина

\begin{abstract}
Аннотация. Цель статьи - представить международные и европейские тренды в стандартизации судебно-экспертной деятельности, уделив особое внимание обязательному при аккредитации экспертных лабораторий стандарту ISO/IEC 17025:2005. Анализируя последовательные действия по упрощению сотрудничества в этой области, повышению практической значимости судебной экспертизы, качества получаемых результатов и их международного признания, автор показывает важность внедрения этого международного стандарта сточки зрения экономической эффективности и рациональности.

Обмен лучшими практиками, базами данных и научным опытом, профессиональная помощь и сотрудничество, беспрепятственный доступ к валидированным лабораторным результатам являются гарантией качества, за которое борется судебная экспертиза (наука и практика), как следует из документа «Создание общего европейского пространства судебно-экспертной деятельности 2020». Есть уверенность, что усилия по стандартизации судебно-экспертной деятельности в Боснии и Герцеговине помогут более эффективной борьбе с терроризмом и организованной преступностью. Иными словами, судебная экспертиза станет более практичной и прозрачной, судебно-экспертные лаборатории - более компетентными, а судебные разбирательства - более эффективными. Таким образом Босния и Герцеговина выполнит часть
\end{abstract}


своих обязательств на пути объединения с Европой, поскольку если лаборатория подтверждает свои результаты, то ее деятельность становится эталонной для судебно-экспертных исследований и установления обстоятельств преступлений.

Ключевые слова: судебная экспертиза, стандартизация, ISO 17025, аккредитация

Для цитирования: Trišić L. International Trends in the Field of Forensic Science Standardization, Forensic Science Standardization in Europe, Experience of Bosnia and Herzegovina // Теория и практика судебной экспертизы. 2018. Том 13. № 3. С. 116-122. https://doi.org/10.30764/1819-2785-2018-13-3$116-122$

\section{Introduction}

The current safety situation in the new century, especially from the aspect of organized crime and terrorism, both having mainly cross-border character, requires a close cooperation between the police and the judicial systems of various countries, i.e. an intensified exchange of forensic data and evidence ${ }^{1}$. This also implies a harmonized norm, i.e. unique international standards to be applied when conducting forensic analysis of traces of perpetrated criminal acts (preparation of evidence for the prosecution of perpetrators). As forensic science and technology develop, the expanding area needs to be regulated in order to make sure that every piece of evidence, from the moment of its discovery at the scene, through the phases of packaging, transporting to the lab, reception, handling by experts, i.e. forensic processing, filing of reports and expert opinion compilation, and their presentation before the court, - is completely safe and protected from any possible damage, malversation, uncontrolled actions, unprofessional handling, contamination, or possible destruction.

All these phases, for the time being, are regulated on the basis of two standards: ISO 17020 - the standard for crime scene inspection operations, and ISO 17025 - the standard for laboratory calibration and testing. The validity of evidence in court depends on their application and observance, that is the competency and capability of a forensic laboratory to perform forensic analyses in accordance with international norms, which is determined by accreditation.

The same norms allow equal acting only if legislation is harmonized as well. This is one of the conditions all the countries are to meet pri-

\footnotetext{
1 Study on Obstacles to Cooperation and Information Sharing Among Forensic Science Laboratories and Other Relevant Bodies of Different Member States and between these and Counterparts in Third Countries, December 2008. P. 72-97.
}

or to joining the EU, including Bosnia and Herzegovina (hereinafter referred to as $\mathrm{BH}$ ), which, after signing the Stabilization and Association Agreement, is trying to obtain a candidate status as soon as possible. After the judicial reform and introduction of prosecutor investigation, this process is underway, and the ubiquitous need for forensic evaluation ${ }^{2}$ and the types of forensic evaluation required through a prosecutor or judge's order, as one of the important segments of a criminal proceeding, is regulated by the laws on criminal procedure on all levels of authority in $\mathrm{BH}^{3}$.

As a rather specific country, $\mathrm{BH}$ still does not have a forensic laboratory accredited according to the ISO 17025 standard, although some activities have begun in this area. It is also obliged by the provisions of the $2005 \operatorname{Pr} m$ Convention and the 2009 EU Council 2009/905/ JHA Framework Decision to do so.

\section{About the international ISO/IEC 17025 standard}

International organizations for standards include the International Organization for

\footnotetext{
${ }^{2}$ Expertise is to be undertaken when a finding or opinion of persons in possession of expert knowledge is to be obtained for establishing or evaluating some important fact. If the scientific, technical or some other expert knowledge can help a court to evaluate or clarify disputable facts, an expert witness can testify by providing findings on these facts and opinion containing the evaluation of the facts (Article 95 from the BH LCP, article 160 from the RS LCP, article 109 from the FBH LCP, and article 95 from the BD LCP) (see footnote 3).

${ }^{3}$ Law on Criminal Procedure of BH (BH Official Gazette, no. $3 / 03,32 / 03,36 / 03,26 / 04,63 / 04,13 / 05,48 / 05,46 / 06$, 76/06, 9/07, 32/07, 53/07, 76/07, 15/08, 58/08, 12/09, 16/09, $93 / 09$ and $72 / 13)$.

Law on Criminal Procedure of the Republic of Srpska, (RS Official Gazette, no. 50/03, 111/04, 115/04, 29/07, 68/07,119/08, 55/09, 80/09, 88/09 and 92/09).

Law on Criminal Procedure of the Federation of $\mathrm{BH}$ (FBH Official Gazette, no. 35/03, 37/03, 56/03, 78/04, 28/05, 55/06, 27/07, 53/07 and 9/09).

Law on Criminal Procedure of Brčko District of Bosnia and Herzegovina (Official Gazette of BD BH, no. 10/03, 48/04, 6/05, 14/07, 19/07, 21/07, 2/08, 17/09 and 9/13).
} 
Standardization $(\text { ISO })^{4}$, the International Electrotechnical Commission (IEC), and the International Telecommunication Union (ITU). The ISO/IEC $17025^{5}$, adopted in 1999, is the first internationally accepted standard prescribing accreditation of laboratories in the sphere of technical demands (staff, accommodation, environmental protection, testing and calibration, method validation, traceability of measurements, sampling, testing object handling methods, ensuring the quality of testing results, calibration, result reporting methods). Quality control on all levels, or the preservation of the "chain of custody" from the moment of first contact with forensic evidence to the presentation of findings and opinion in court, satisfaction of the final user, prevention of conflicts of interests, comparability of measurements, reliability of results, costeffectiveness are the characteristics giving an advantage to this standard over the all the national standards in existence at that time.

The American National Standards Institute (ANSI) was established in 1918 and represents the country in the ISO and IEC. The American Society of Crime Laboratory Directors (ASCLD) is an international organization promoting excellency through leadership management, and an accreditation body that has set the standards a laboratory has to meet in order to get their accreditation. After the recognition of DNA analysis as a new forensic technique by American courts in 1987, scientific practitioner groups from the USA and Canada have contributed significantly to the standardization of this forensic field through their activities since the year of 1988, as well as the European Network of Forensic Science Institutes (ENFSI) since 1995, and the UK Forensic Science Regulator since 2008.

Forensic DNA laboratories in the USA are usually accredited according to ISO/IEC 17025 , with the FBI standards for quality assurance serving as a primary supplement document. Access to the National DNA Database and federal donor databanks depends on successful accreditation of American DNA laboratories according to these standards.

From the Pr m document (2005), which obliges all EU members to exchange forensic in-

\footnotetext{
${ }^{4}$ International Organization of Standardization, 2017. http:// www.iso.org/iso/home.html

5 BAS EN/ISO/IEC 17025, General requirements for the competence of testing and calibration laboratories (EN ISO/ IEC 17025:2005, IDT), 2006.

What is ISO/IEC 17025? Why is it important? http://www. pipetpeoplestore.com/index.cfm/fuseaction/home.showpage/ pagelD/108/index.htm
}

formation on DNA analyses, dactyloscopy and vehicles, the EU Council Decision 208/615/ JHA dated June $23,2008^{6}$ on strengthening cross-border cooperation, particularly in combating terrorism and organized crime, to its modified version in the EU Council Decision $2009 / 905 / \mathrm{JHA}^{7}$, which pertains to the accreditation of forensic institutes, it is clear that accreditation of forensic laboratories is a condition for quality work performance, participation in the safety and judicial system, and further existence on the forensic examination market in the first place.

According to this latest decision, all the EU members were obligated to:

- have their DNA laboratories accredited no later than November 30, 2013,

- have their dactyloscopy laboratories accredited no later than November 30, 2015,

- incorporate the provisions of the EU Council Decision 2009/905/JHA dated May 30, 2016 into their national legislative systems.

The EU Commission is obligated to submit a report to the EU Council no later than July 1,2018 on the implementation of these measures, which will determine the extent of the obligations fulfilled by the end of 2018.

At the time of presiding over the EU, Poland submitted the Polish Forensic Initiative that was accepted according to the document titled the Creation of the Common European Area for Forensic Science $2020^{8}$ prescribing the following:

- accreditation of all forensic laboratories and institutions in the EU,

- obeying the minimum competency criteria for forensic laboratory employees,

- establishing unique, standardized practical handbooks and their application in forensic laboratory practice,

- implementation of international interlaboratory tests,

- identifying optimal ways for transnational forensic data bases and their application,

\footnotetext{
${ }^{6}$ Council Decision 2008/615/JHA of 23 June 2008 on the stepping up of cross-border cooperation, particularly in combating terrorism and cross-border crime (Prüm Decision on the exchange of unidentified DNA profiles, dactyloscopic data and vehicle registration data).

${ }^{7}$ Council Framework Decision 2009/905/JHA of 30 November 2009 on Accreditation of forensic service providers carrying out laboratory activities (Stockholm Programme. Accreditation of forensic institutes on DNA and Dactyloscopy).

8 3135th JUSTICE and HOME AFFAIRS Council meeting. Brussels, 13th and 14th of December 2011. Council conclusions on the vision for European Forensic Science 2020 including the creation of a European Forensic Science Area and the development of forensic science infrastructure in Europe. 37 p.
} 
- standardization in the field of education and forensic science training,

- obligation to incorporate the EU segment for investigation and development into the forensic institutions/laboratories.

Also, the Polish initiative for establishing a European technical committee for standardization in forensic science, the CEN/TC 419 for engagement and the implementation of the ISO/IEC 17020 standard that pertains to the protection of evidence at the scene was accepted. In order to prevent its duplication in some other part of the world, the CEN/TC 419 has been shifted to global level and is implemented by the International Standardization Organization Committee ISO/TC272 for forensic science.

Although certification and accreditation will not prevent mistakes, eliminate misinterpretations and deliberate misuse, they will still lead to the reduction of possible mistakes, and thus improve the trust of both the judiciary and the public in forensic science [1].

\section{Forensic laboratories of the European Union}

Forensic laboratory accreditation that meets the international ISO/IEC 17025 criteria is conducted by a government accreditation body. Accreditation guarantees the competence of a forensic laboratory to perform forensic examinations, while certification results in a certificate of conformity of the management system and the examinations conducted by a forensic laboratory with the international ISO 17025 standard [2].

Lately, there have been some tendencies for greater autonomy among forensic laboratories in the European territory. Powerful development of new technologies, improvement of forensic examination results, which become more present in all types of court proceedings, but also constant reduction of finances for investing in and maintaining the bulky forensic systems have imposed the need of reconstructing the existing laboratory systems in the EU countries. Introduction of DNA analysis methods into the system of crime detection has become the most powerful weapon of forensic science for personal identification, and very popular among the public. Also, the reliability of these results has disturbed the proportion of previous forms of expertise in forensic institutions.

When analyzing the benefits of modern forensic capabilities expected by the legal system (forensic tools and forensic techniques will be available at the scene - mini laboratories, operations, reduced time of the finding composition, expertise reliability, etc.), one can say that forensic science is becoming a relatively cheap and effective field of crime detection. Technological progress, i.e. introduction of sophisticated techniques, primarily in the field of DNA and IT expertise, adds significance to the evidence obtained. Introduction of forensic analytics and the possibility to obtain a preliminary finding makes a forensic laboratory a lot closer to a service user, whilst the existence of an organized investigation and development segment is a good combination of professional experience and forensic science perspectives projected on this experience [3].

Several models of organizing a forensic institution are present in practice: from the classical form of all types of expertise (most European countries) to specialized institutions engaged in specific types of forensic analysis (medical, chemical-toxicological, IT or economics).

Great Britain, for example, has greatly "dissembled", i.e. broken into pieces and privatized its old system of forensic analysis. Holland, due to expansion of the work volume, has reduced the types of expertise following the principle of frequency and proven significance, and tripled the number of employees at the end. There are also new models of organization in the form of specialized forensic institutions that exclusively analyze submitted evidence without visiting the scene (Agency for Forensic and Expert Examinations - AFIV BH).

Within the forensic community, there is a dilemma as to whether forensic laboratories examining the evidence should remain within the police and judicial institutions or act independently. A very serious argument in favor of autonomy is that the one gathering the evidence should not be the one analyzing it. In other words, impartiality, professionalism and prevention of the conflict of interests are all part of the European professional forensic standards. No matter which concept prevails, it is important for it to be functional and professionally independent, and to contribute to the basic goal: a timely and improved analysis of traces of perpetrated criminal acts for the sake of efficient establishment of facts and welltimed court proceedings.

\section{Situation in Bosnia and Herzegovina}

As a country that has signed the Agreement on Stabilization and Association, and whose 
main strategic goal is $\mathrm{EU}^{9}$ integration, $\mathrm{BH}$ has an obligation to harmonize its judicial system with the EU legislation. International exchange of forensic data bases is one of the obligations on this way. The political and safety situation aggravated due to existence and activities of extremists from the Mujahideen community, ex-members of the El-Mujahideen Squad that have stayed in $\mathrm{BH}$ after taking part in the civil war (recruitment for the Syrian battlegrounds, return of the fighters from Syria, terrorist attack on the USA Embassy in Sarajevo, terrorist attacks with human fatalities at police stations in Bugojno and Zvornik, members of the $\mathrm{BH}$ armed forces in Rajlovac near Sarajevo), and all forms of general and organized crime, often involving a cross-border component, specific for a country in transition, requires a quality, well equipped, and professionally staffed laboratory for the most complex forensic analyses and crime expertise. Therefore, the efforts of some forensic institutions to obtain the ISO/ IEC 17025 accreditation are reasonable.

The situation in the field ${ }^{10}$ and the expert analyses of the local experts and those from the international community engaged through the IPA pre-accession projects (experts from Germany, Slovenia, Croatia), USAID's project and similar ones providing support in the judicial and safety fields, suggest that the situation is still not ripe for taking such a big step toward the validation of forensic findings. Unfortunately, subjectivity, and even personal interests, often have negative impact on forensic science and its desired development in $\mathrm{BH}$. Therefore, it is no surprise that the accreditation attempted within the ENFA-2 "Flying mentors", financed and led by the ENFSI, of the Forensic and Information Support Centre of the Federation of Bosnia and Herzegovina Federal Police Department (FUP MUP BiH) has failed [4]. Due to the failure to obtain accreditation within the stipulated three-year period, the FUP MUP BiH has lost its membership with ENFSI.

The government-level agency for forensic examinations and expertise along with the Republic of Srpska Ministry of Internal Affairs Crime-Technical Centre (KTC MUP RS) have similar tendencies. However, according to the latest report of the Croatian forensic experts (2017) engaged with the IPA project in the field of safety and accreditation of the $\mathrm{BH}$ forensic laboratories, none of the 16 forensic facilities

\footnotetext{
${ }^{9}$ Document "The BH Safety Politics". 2006. P. 1.

${ }^{10}$ The list of accredited bodies for conformity validation as of $17^{\text {th }}$ of April, 2017, Bata Accreditation. http://www.bata.gov.ba
}

in the field of $\mathrm{BH}$ safety ${ }^{11}$ meets the necessary criteria stipulated by the international ISO/IEC 17025 standard. Some forensic laboratories do not have an adequate space required by the expert standards, others do not possess sophisticated equipment prescribed by the technical standards, some have expertise performed by incompetent and unprofessional staff. This raises questions regarding the purpose of such divided forensic activity in $\mathrm{BH}$ (3.5 million inhabitants), and the validity of their expertise in general.

These remarks are also confirmed by the findings and recommendations of the analysis of expert witness system of engagement in cases of corruption, organized crime and economic crimes $^{12}$, as well as by the preceding diagnostic analysis of the $\mathrm{BH}$ judicial sector integrity and possible risks of corruption or unethical conduct in the judicial system (diagnostic analysis, DA), which "has identified the work scope of the court experts as an area of possible violation of the legal system integrity and corruption due to way of their engagement by courts and prosecutors' offices, lack of supervision and possible problems related to the integrity of the expert witnesses" 13 .

The same is said in the following observation: "During the initial discussions with prosecutors working on the cases of economic crime and corruption, it has been pointed out that the expertise is often of unsatisfactory quality, copied from the reports on committed criminal acts submitted by the law enforcement agencies, as well as that the expert witnesses do not possess enough basic knowledge on the elements of criminal acts which can result in their wrong direction during the finding elaboration..."14

It is hard to list all the anomalies mentioned in this document, but it is telling that " $85 \%$ of the surveyed prosecutors have stated that often there is a need for an additional explanation of expert witnesses' findings and opinions during the hearings, whilst $47 \%$ of the surveyed prosecutors witness the cases in practice when the findings and opinion submitted do not meet

\footnotetext{
11 Agency for forensic examinations and expertise (on the government level), FUP MUP FBiH and the KTC MUP RS (both on the entity level), Brčko District Police forensic, and the 10 forensic departments of cantonal MIA, as well as certain forensic facilities of the Border Police and the Agency for Investigations and Protection not having a jurisdiction over this subject matter.

${ }^{12}$ Analysis of the system of engagement of court experts in cases of corruption, organized and economic crime, USAID project of $\mathrm{BH}$ judicial system, December 2017. www.usaidjp.ba 13 Ibid. P. 11.

${ }^{14}$ Ibid. P. 26
} 
the expertise order criteria resulting in ordering an elaboration of a new expert witness's finding and opinion" 15 .

Unprofessional work attitude, lack of sufficient professional knowledge and personal integrity, absence of the evaluation mechanism, as well as the obsolete, outdated, inflexible legislation that contradicts international standards are only some of the reasons of this unfavorable situation, which instead of contributing to actual and effective court proceedings through professional competence and quality is making the court proceeding even more complicated and the $\mathrm{BH}$ legal system less trustworthy. What other explanation can be provided for the situation in which an individual that has never performed the role of an expert gets the position of a permanent expert witness and takes more than half a year to process a single case, while on the other hand, forensic expertise deadlines in the international forensic community are being reduced ( 3 days for "fast track" investigations, 14 days for medium ones, and 90 days for the long ones)? The same examiner may refuse to perform an examination with no obvious reason, and by doing so undermine the jurisdiction of the prosecutor in charge of a case, or reveal scientific information on the case he is in charge of to other prosecutors, willingly getting involved in a conflict of interests, and still remaining unsanctioned by the association of professional organizations or the competent institution that, according to the Law on Expert Witnesses ${ }^{16}$, is in charge of monitoring the permanent expert witnesses' performance and extension of their licenses.

How far the destruction of such an important activity goes is best shown by the case of the government-level Agency for Forensic Examination and Expertise in which the CEO deputy position is held by an individual who is a subject of an ongoing organized crime trial, and the criminal acts he has been charged with

\footnotetext{
15 Ibid. P. 64

${ }^{16}$ Law on Expert Witness ("FBH Official Gazette", no. 49/05 and 38/08), Law on Expert Witnesses ("RS Official Gazette", no. $16 / 05,65 / 08$ and 74/17), the Rulebook on the Criteria for Carrying Out the Expertise Tasks ("BH Brčko District Official Gazette", no. 38/16).
}

\section{REFERENCES}

1. Weedn V.W., Ask Experts about Forensic Certification and Accreditation, Criminal Justice. 2010. No. 25. P. 48-51.

2. Ivanović B.A., Ivanović R.A. Forenzički izazovi XXI veka. Zbornik radova: I naučne konferencije sa međunarodnim učešćem - Pravni iza- in the $10,000,000.00 \mathrm{KM}+$ case include misuse of power and collusion when appointing a new CEO of this very institution, both men in possession of no police and forensic experience whatsoever. It can be concluded that the accreditation process is still very far from becoming reality.

\section{Conclusion}

Forensic science standardization and accreditation of forensic laboratories in line with international standards is a new century imperative. The spread of criminal activity that knows no borders, development of new technologies and modern expertise methods for proving even the most difficult cases will provide for the growing importance of forensic science. Cooperation in the field of crime investigations and exchange of forensic data bases are activities that have no alternative, while forensic laboratory accreditation is something we all benefit from - politicians, scientists, professionals, or manufacturers.

International standardization, elaboration of professional procedures, uniform data bases, secured chain of custody, professional evidence handling, impartial and objective findings and opinions of educated and dedicated forensic experts with high professional integrity, cooperation with prosecutors and judges form the foundation for effective detection of even the most serious criminal acts. Harmonization with the EU legislation and adoption of quality laws that will make the selection, necessary training and expert witness certification more rigorous is an obligation $\mathrm{BH}$ has to fulfill without delay in order to be able to benefit from the useful development of the judicial system and involvement in the process of international data exchange.

In reaching this goal, $\mathrm{BH}$ will need a lot more international cooperation tailored to actual needs and political power in order to have this area regulated according to international standards of the profession, and finally start functioning for the benefit of all $\mathrm{BH}$ citizens and for the sake of professional partnership with all the countries ready to cooperate in accordance with these principles.

zovi na početku XXI veka, Internacionalni univerzitet u Novom Pazaru, 2011, str. 105-123. [Ivanović B.A., Ivanović R.A. Forensic challenges of the $21^{\text {st }}$ century. Collection of works: The first scientific conference with international participation - The Legal Challenges at the Begin- 
ning of the $21^{\text {st }}$ Century. International University in Novi Pazar, 2011. P. 105-123. (In Serbian)].

3. Ivanović R.A., Ivanović B.A. Forenzička akreditacija - pouzdan način dokazivanja, Internacionalna asocijacija kriminalista. Zbornik radova: VII naučna konferencija sa međunarodnim učešćem - Kriminalistički i krivično procesni aspekti dokaza i dokazivanja, Sarajevo, 2013. Str. 353-364. [Ivanović R.A., Ivanović B.A. Forensic accreditation - a reliable means of proof. The International Association of Criminologists. Collection of works: the $7^{\text {th }}$ scientific conference with international

\section{ABOUT THE AUTHOR}

Trišić Ljiljana - Independent Expert on Internal Affairs and Security, Ex-Director of the Agency for Forensic and Expert Examinations (2009-2017), Bosnia and Herzegovina; e-mail: Ijiljana.trisic@ gmail.com. participants - The Criminalistics and Criminal Procedure Aspects of Evidence and Proof. Sarajevo, 2013. P. 353-364. (In Serbian)].

4. Bojanić N., Bajraktarević-Pajević D. Uvođenje sistema kontrole kvaliteta kriminalističkih vještačenja u Bosni i Hercegovini, Bezbednost 1/17, Beograd, str. 78-93. DOI:10.5937/ bezbednost1701078B. [Bojanić N., BajraktarevićPajević D. Introduction of the quality control system of criminal expertise in Bosnia and Herzegovina. Bezbednost, Beograd. 2017. Vol. 59. No. 1. P. 78-93. (In Serbian). DOI: 10.5937/bezbednost1701078B].

\section{ИНФОРМАЦИЯ ОБ АВТОРЕ}

Тришич Лилиана - Независимый эксперт по внутренним делам и безопасности, бывший директор Агентства судебных экспертиз (20092017) Боснии и Герцеговины; e-mail: Ijiljana. trisic@gmail.com. 